\title{
Remediation potential of Baobab (Adansonia digitata L.) Seedlings grown in sewage sludge contaminated by Heavy Metals
}

\section{AKINTOLA, OO; ADEROUNMU, AF; ABIOLA, IO; BODEDE, IA}

\author{
Forestry Research Institute of Nigeria, P.M.B 5054 Jericho Hill, Ibadan, Oyo State, Nigeria
}

*Corresponding Author Email: toyinakintola73@gmail.com

\begin{abstract}
Application of sewage sludge to agricultural land is widely practiced and presumed to be beneficial for plants' growth. However, sewage sludge is often contaminated by heavy metals, organic pollutants, and pathogens. This study assessed the capacity of Adansonia digitata seedlings to accumulate and distribute heavy metals from sewage sludge into their tissue parts. Respective heavy metals concentrations in soil before and after plantings were $\mathrm{Cu}(55.68 ; 26.45)$, $\mathrm{Zn}$ (76.22; 48.06), $\mathrm{Pb}(28.22 ; 19.58), \mathrm{Ni}(22.76 ; 19.32), \mathrm{Cd}(3.11 ; 1.49), \mathrm{Cr}(41.78 ; 23.39)$ and $\mathrm{As}(5.92 ; 4.71) \mathrm{in} \mathrm{mg} / \mathrm{kg}$ and these were higher than those from control soil. Heavy metals concentrations $(\mathrm{mg} / \mathrm{kg})$ in roots of plants from sewage sludge and control soils were $\mathrm{Cu}$ (3.08- 16.01), $\mathrm{Zn}$ (4.25-9.83), $\mathrm{Pb}$ (1.21-3.74), $\mathrm{Ni}(0.33-1.57), \mathrm{Cd}(0.17-0.93)$ and $\mathrm{Cr}$ (2.23-6.65) while those of the shoots were $\mathrm{Cu}$ (4.61-30.11), Zn (5.88-16.22). Pb (1.41-4.86), Ni (0.27-1.56), Cd (0.09$0.65)$ and $\mathrm{Cr}$ (3.24-10.01). For most of the studied metals, bioaccumulation factor (BCF) values were more than one and generally higher for $\mathrm{Cr}, \mathrm{Zn}, \mathrm{Cu}$, and $\mathrm{Pb}$. The significant reduction observed in concentrations of heavy metals in soils before and after planting indicated their enrichment in the plant tissues. Bioconcentration factors indicated that Adansonia digitata can be used as bioaccumulation plant. This study has shown the efficacy and ability of Adansonia digitata to accumulate and distribute heavy metals in its tissue parts.
\end{abstract}

DOI: https://dx.doi.org/10.4314/jasem.v23i9.14

Copyright: Copyright (C) 2019 Akintola et al. This is an open access article distributed under the Creative Commons Attribution License (CCL), which permits unrestricted use, distribution, and reproduction in any medium, provided the original work is properly cited.

Dates: Received: 12 August 2019; Revised: 17 September 2019; 20 September 2019

Keywords: Bioaccumulation, heavy metals, enrichment, sewage sludge

Application of residuals disposal such as sewage sludge to agricultural land is extensively adept and assumed to be favorable for plants' growth (Liphadzi and Kirkham, 2006). Sewage sludge is the residual, semi-solid material formed as a by-product during sewage treatment of industrial or municipal wastewater and often contaminated by heavy metals $(\mathrm{Cd}, \mathrm{Pb}, \mathrm{Zn}, \mathrm{Cu}, \mathrm{As}, \mathrm{Cr}, \mathrm{Ni})$, organic pollutants [polycyclic aromatic hydrocarbons (PAHs), polychlorinated biphenyls (PCBs), and phthalic acid esters (PAEs)], and pathogens (Suchkova et al., 2014). Due to huge production of sewage sludge around the world, there is a need for its management. Two major disposal strategies for sewage sludge management are reuse (agriculture or landscaping purposes) and final disposal. Although several options for management of sewage sludge such as anaerobic digestion, composting and incineration in combination with energy recovery as stated by Mininni et al (1997) do exist. Thus, the processing of sewage sludge in order to achieve important products is becoming more popular. Its usage in agriculture is strictly regulated in developed countries. However, in many developing countries, there is an increasing agricultural usage of sewage sludge due to its richness in organic matter, nitrogen and phosphorus. A notable management of sewage sludge is its usage for agricultural purposes because it is an important source of micro- and macronutrients for plants, a high water holding capacity and anaerobic conditions and its high content of organic matter, thus making it an extremely suitable soil conditioner (Singh and Agrawal, 2008). However, despite its valuable characteristics and usage (Cocarta et al., 2017; Eid et al., 2017), there are several restrictions on its usage as regard the given management method (Kacprzak et al., 2017). Although, the availability of toxic heavy metals in sewage sludge to plants through soils are minima but they are still a major concerned because their accumulation in plants may be harmful to the environment and, in particular, to the food chain. Thus may be a potential risk to human health, in particular those linked to trace elements (TEs), such as heavy metals and organic contaminants present in the sewage sludge (Fijalkowski et al., 2017). The potential toxicity of sewage sludge can be caused by xenobiotics, antibiotics, or heavy metals (Wołejko et al., 2017). Thus, the use of a green of green plants to remediate (heavy metals and other from contaminated sludge could be an important means in improving its quality with a more economical and environmentallyfriendly approach. The successful application of 
phytoremediation techniques depend on many factors such as bioavailability of the contaminants and their readiness to be absorbed by roots of the plants. The bioavailability of heavy metals depends from their solubility of the in soil. In addition to this, mechanisms and effectiveness of the phytoremediation depend also on others factors such as the nature of contaminant, soil properties, and plant species (Sreelal and Jayanthi, 2017). The plants which are generally considered for this purpose are those that exhibit great efficiency in phytoremediation processes. Several approaches have been attempted by many authors to sewage sludge phytoremediation in recent years. These include the application of certain amount of sewage sludge with other growing media (soil) on agriculture (Antonkiewicz et al., 2016; Chu et al., 2017; Wyrwicka and Urbaniak, 2018) or forest species (Grobelak et al., 2017) but only a few studies have been done where remediation was assessed on sewage sludge without dilution. This study thus investigated the efficiency of Adansonia digitata seedlings for remediation of sewage sludge deposits by assessing its potential to uptake heavy metals and their bioaccumulation in the seedling parts.

\section{MATERIAL AND METHODS}

Site description: A pot experiment was carried out in Screen house of Forestry Technology Department, Federal College of Forestry, Ibadan, Oyo state. The experimental site lies between Latitude $7^{\circ} 26^{\prime} \mathrm{N}$ and Longitude $3^{\circ} 54^{\prime} \mathrm{E}$. The climate of the area is tropical. The annual rainfall ranges from $1400 \mathrm{~mm}-1500 \mathrm{~mm}$ and average relative humidity of about $65 \%$, the average temperature is $31.80 \mathrm{C}$. The area is dominated by two seasons: the dry season and rainy season. The rainy season usually begins from November to March, while the rainy season starts from April to October (FRIN Meteorological Station, 2015). Seeds of $A$. digitata were obtained from Forestry Research Institute of Nigeria (FRIN), Ibadan, Oyo State, Nigeria. Sewage sludge was collected from effluent discharge at the back of NNPC depot, Ibadan Southwestern Nigeria. The control soil was collected within the same locality where there is no trace of contamination. Both the growing media were air-dried and sieved using $2 \mathrm{~mm}$ sieve to remove stones, roots and other materials that may be detrimental to the emergence of the young plants from the seeds. The seeds were planted in the polythene pots of $25 \mathrm{~cm}$ by $30 \mathrm{~cm}$ with $2 \mathrm{~kg}$ of treatment soils. The experimental pots were watered every three days, and subsequently during the course of the experiment, the weeding of the pots was done by hand. After four weeks (4weeks) of planting, the population of surviving plants was reduced to three plants per pot by thinning. The pots were arranged in a completely randomized design consisting two treatments replicated ten times making a total of twenty (20) pots for the plant.

Growth parameter assessment: The growth parameters of the plants were taken weekly using a meter rule to measure plant height, vernier caliper to measure stem diameter, and counting the number of leaves. After 14 weeks of sowing the seeds, the plants were harvested before leaf shedding to determine biomass weight.

Sample preparation and analyses: Soil samples were air dried, crushed and passed through a $2 \mathrm{~mm}$ sieve. Soil samples were analyzed prior to experimentation and after harvesting for some chemical properties. Before planting, physiochemical parameters including soil texture, $\mathrm{pH}$, organic matter concentration, exchangeable $\mathrm{Ca}, \mathrm{Na}, \mathrm{K}, \mathrm{Mg}$ concentrations, total $\mathrm{N}$ and $\mathrm{P}$ concentration, $\mathrm{CEC}$, were also determined according to the standard instrumentation procedures (Roades, 1996). The plant samples were washed with distilled water to remove dirt and dust. The samples were separated into portions of roots, stems, and leaves and air dried for three weeks. The dried samples were ground into powder using ceramic pestle and mortar and sieved to obtain fine powder. Each powdered samples of the plant parts were weighed into $100 \mathrm{~cm} 3$ beaker of known weights and oven dried at a temperature of $105^{\circ} \mathrm{C}$ until a constant weight was reached. Each of the samples (15g) was stored in an air tight container. Sample solution was prepared by digesting $10 \mathrm{~g}$ of each sample which has been ashed at $550^{\circ} \mathrm{C}$ using $10 \mathrm{~cm}^{3}$ of $6 \mathrm{M}$ nitric acid. The mixture was filtered into $50 \mathrm{~cm}^{3}$ volumetric flasks and de-ionized water was added up to the mark. The solutions were analyzed for $\mathrm{Cu}, \mathrm{Zn}, \mathrm{Pb}, \mathrm{Cr}, \mathrm{Ni}, \mathrm{Cd}$ and $\mathrm{As}$, using atomic absorption spectrophotometer (model Perkin Elmer 3110). A procedural blank and a set of standard for each metal were determined each time a series of samples were run. Average readings of the samples were corrected with the blank reading and a calibration curve was constructed for each standard solution. The concentrations of each element under investigation in $\mathrm{mg} / \mathrm{kg}$ were determined from the curve of its standard by interpolation.

Data Analyses: A percentage reduction index (RI) was calculated using equation 1

$$
R I(\%)=C b p-C a p / C b p \times 100 \quad 1
$$

Where Cbp and Cap are concentrations of heavy metals in the growing media before and after planting respectively. In order to assess the potential of $\mathrm{A}$. digitata seedlings for phytoremediation, the 
bioconcen-tration factor (BCF) was calculated using the formula given by Zhang et al (2010) in equation 2 .

$$
B C F=\text { Conc. of heavy metals in } \frac{\text { shoot }}{\text { soil }} 2
$$

Data obtained were analyzed using analysis of variance (ANOVA) and the significant differences were evaluated post-hoc using Tukey's HSD test with a level of significance of $p<0.05$. ANOVA was performed with SPSS version 21. Variations in soil contaminants before and after plantings were assessed.

\section{RESULTS AND DISCUSSIONS}

Properties of the growing media: Results of the chemical characteristics of the sewage sludge and the control soil before planting were presented in Table 1. The texture of the soil in the potting media were sand (75- $80 \%)$, Silt (15-18\%) and clay (5-7\%) indicating sandy loamy soil. Texture is an important soil characteristic that plays important role in soil management and crop production. Sandy loam texture is suitable for seedling growth and development because it contains high nutrients, CEC and highwater holding capacity (Majid et al, 2012). Soil pH in the potting media before planting ranged from 5.5 to 7.50. The $\mathrm{pH}$ of the sewage sludge is slightly acidic while that of control is slightly basic. The $\mathrm{pH}$ is a major factor influencing the availability of elements in the soil for plant uptake and most metals are more soluble and available in the soil solution at $\mathrm{pH}$ below 5.5 (McBride, 1994).

Table 1. Chemical characteristics of the growing media before planting

\begin{tabular}{lllll}
\hline Parameters & & Sewage sludge & control & $\begin{array}{c}\text { Maximum values given by } \\
\text { DPR(2002) in mg/kg }\end{array}$ \\
\hline Physical & & & 75 & \\
and chemical & Sand (\%) & 80 & 18 & \\
properties & Silt (\%) & 15 & 7 & \\
& Clay (\%) & 5 & 7.50 & \\
& $\mathrm{pH}$ & 5.50 & 3.30 & \\
& Organic matter (\%) & 27.80 & 15.22 & \\
& Total N (mg/kg) & 56.88 & 2.16 & \\
& Total P (mg/kg) & 5.22 & & \\
Heavy & & & 35.09 & 140 \\
$(\mathbf{m g} / \mathbf{k g})$ & metals & 76.22 & 17.91 & 36 \\
& $\mathrm{Zn}$ & 55.68 & 12.26 & 85 \\
& $\mathrm{Cb}$ & 28.22 & 5.21 & 35 \\
& $\mathrm{Pi}$ & 5.92 & 0.50 & 1.8 \\
& $\mathrm{Ns}$ & 3.11 & 1.01 & 0.8 \\
& $\mathrm{Cd}$ & 41.78 & 15.11 & 100 \\
\hline
\end{tabular}

Thus, metals are more available in soil solution for root absorption at low $\mathrm{pH}$ due decrease in retention of metals to soil organic matter. Values of organic matter content in the sewage sludge and control soil were 27.80 and $3.30 \mathrm{mg} / \mathrm{kg}$ respectively. The respective concentration of total nitrogen $(\mathrm{N})$ in the sewage sludge and the control samples were 56.88 and 15.22 while that of total phosphorus (P) were 5.22 and 2.16 $\mathrm{mg} / \mathrm{kg}$ respectively. According to Wyrwicka and Urbaniak, (2018) and Carbonell et al (2009), sewage sludge usually contains high levels of organic matter and is rich in $\mathrm{N}$ and $\mathrm{P}$ and this makes it a good growing medium for plants and has been used as a fertilizer in forestry and agriculture. Thus the results of this study further strengthen and support the past studies. Furthermore, Kelessidis and Stasinakis (2012) stated that Sewage sludge may also contain inorganic (e.g. TEs) and organic (e.g.PAHs, n-alkanes, PCBs) compounds removed from the wastewater which can be harmful to a plant's metabolism and concluded that these biological consideration along with local legal constraints and regulations, make the recycling of sewage in agriculture and forestry a challenging issue.
The results of heavy metal concentrations in the growing media were $\mathrm{Zn}$ (35.09 - 76.22), $\mathrm{Cu}$ (17.91 55.68), Pb (12.26 - 28.22), Ni (6.21 -22.76), As (0.50 - 5.92), Cd (1.01 - 3.11) and Cr (15.11- 41.78) in $\mathrm{mg} / \mathrm{kg}$ and this is high when compared with the control soil (Table 1). The concentrations of heavy metals in the sewage sludge used were lower than the values obtained from similar studies and recommended values (DPR, 2002; Suchkova et al., 2014; Guidi Nissim et al., 2018).

Growth parameters of $A$. digitata in the growing media: Weekly mean values of seedling heights stem diameter and leaf production were presented in figure 1 -3 . It was observed that the grow parameters in sewage sludge (T1) was greater than those in control site from week 1 to 14 . The increase in the growth parameters could be attributed to the soil being rich in organic matter which is the source of most of the nitrogen and phosphorus which enhances soil fertility and promote plant growth (Ideriah et al., 2010). Also the activities of soil organisms in the decomposition of these wastes may have accounted for the rich nutrient contents of 
the soil which in turn has increased the growth of the plant (Obute et al., 2010; Amos-Tautua et al., 2014). Slight reduction noticed in the growth of the plants towards the end of the experiments could be due to interference with the soil-water-relation as well as nutrient immobilization and the presence of heavy metals (Akintola, 2019; Akintola and Bodede, 2019). There was a significant difference among the seedlings grown in sewage sludge and control soil. The biomass of the plant varied significantly. The results showed that biomass production for plants gradually increased with treatments (Table 2). The increase in the values of biomass production of the plants in the growing media were in agreement with past studies (Suchkova et al., 2015; Guidi and Labrecque, 2016; Leila et al., 2017, Akintola and Bodede, 2019), and there were no significant differences in biomass production between the growing media indicating that no phenomena of severe plant stress occurred or induce phytotoxicity symptoms in the plant during the experiment.

Heavy Metals concentrations in the growing media: Heavy metal contaminants which usually come from industrial activities, such as mining and smelting of metalliferous ores, electroplating, gas exhaust, energy and fuel production, fertilizer and pesticide application, sewage sludge and generation of municipal wastes are $\mathrm{Cd}, \mathrm{Cr}, \mathrm{Cu}, \mathrm{Hg}, \mathrm{Pb}$, and $\mathrm{Zn}$ (Kabata-Pendias, 2011). Heavy metals concentrations in the potting media before and after planting (BP and AP) are presented in Table 3. Heavy metal concentrations in soil before planting were found to be significantly higher than after planting. Heavy metal concentrations in sewage sludge soils (T2) were higher than those of control (T1). Four heavy metals concentrations $(\mathrm{Cu}, \mathrm{Cr}, \mathrm{Pb}$ and $\mathrm{Zn})$ showed significant decrease in sludge (T1) and soil concentrations (T2) when compared with their concentrations before planting values though the extent of the reduction varied among the metals (Table 3 ).

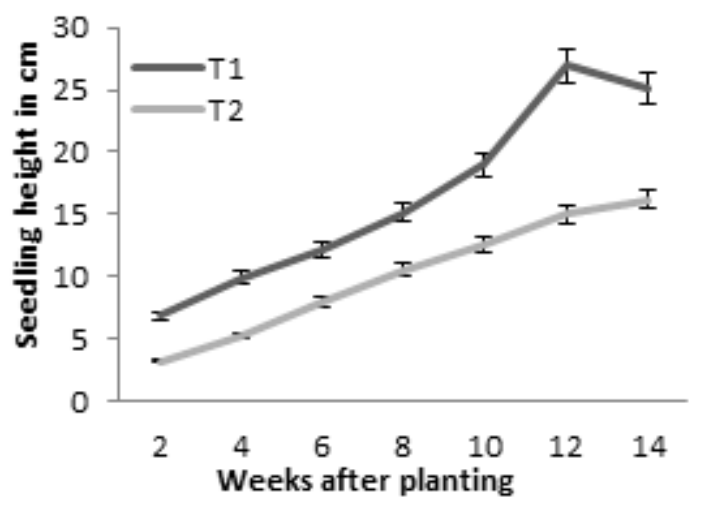

Fig 1. Mean seedlings height of the $A$. digitata

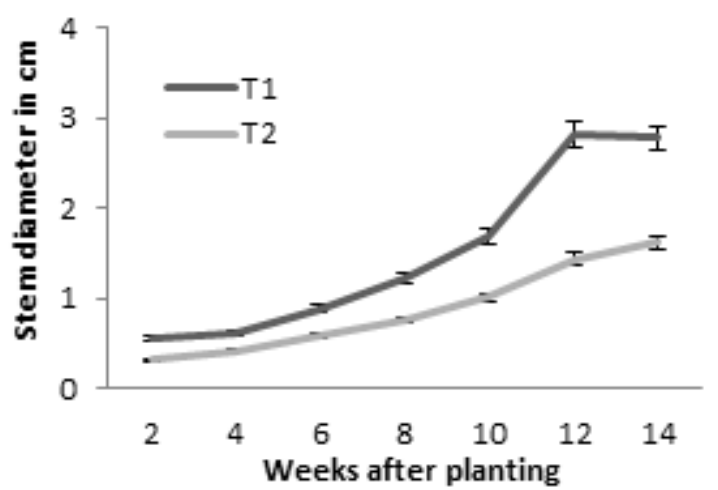

Fig 2. Mean Stem diameter of the A. digitata

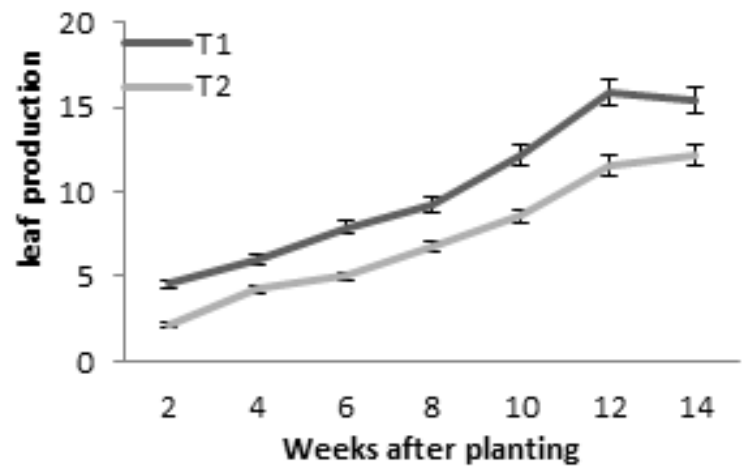

Fig 3. Mean Leaf production of the $A$. digitata

Table 2. Mean Biomass production values of A. digitata

\begin{tabular}{llll}
\hline Treatments & \multicolumn{3}{l}{ Biomass production in $\mathbf{g}$} \\
\cline { 2 - 4 } & leaves & stems & Roots \\
\hline T1 & $55.68 \pm 0.50$ & $65.22 \pm 0.62$ & $71.22 \pm 0.67$ \\
T2 & $46.21 \pm 0.42$ & $59.99 \pm 0.51$ & $62.89 \pm 0.58$ \\
\hline
\end{tabular}

The reduction index in percentage of studied metals in both treatments were in the order of $\mathrm{Cu}(43.11-55.34)$ $>\mathrm{Cr}(36.22-45.01)>\mathrm{Zn}(28.09-3.95)>\mathrm{Pb}(21.56-$ $30.61)>\mathrm{Ni}(9.56-15.01)>\mathrm{Cd}(3.15-5.22)$. As showed reduction index values of $2.02 \%$ in sewage sludge while that of control soil could not be calculated because the concentration after planting in the soil was below detection limit (Table 3). Observed reductions in the heavy metal concentrations in soil after planting can be attributed to the ability $A$. digitata to uptake heavy metals from the soils and this is similar to the findings of Akintola and Bodede, 2019. High reduction in $\mathrm{Zn}, \mathrm{Cr}$ and $\mathrm{Cu}$ concentration in the growth media after planting may be due to their important in metabolic activities of plants (Marcel, 2006). Low reduction index value of the $\mathrm{Pb}$ compared to $\mathrm{Cu}$ and $\mathrm{Zn}$ can be due to its not essential to plants. Most frequently inorganic pollutant in the soils is lead $(\mathrm{Pb})$ and is not an essential element but can be toxic even at low concentrations to plants, animals and human and above $400 \mathrm{mg} / \mathrm{kg}$ can be hazardous to human health (USEPA, 2001). The significant reduction of some of the heavy metals in the growth media showed the level 
of heavy metal enrichment in A. digitata seedlings. The fact that some heavy metals $(\mathrm{Ni}, \mathrm{Cd}$ and $\mathrm{As})$ decreased (although not significantly) with time could be attributed to some minor leaching phenomena that occurred while irrigating (Guidi Nissim et al., 2018). Higher reduction index of heavy metal concentration were noticed in the sewage sludge (T1) than control soil. (T2)

Table 3. Heavy metal concentrations in the soils before and after planting

\begin{tabular}{lllllll}
\hline Heavy metals (mg/kg) & \multicolumn{3}{c}{ Sewage sludge (T1) } & \multicolumn{3}{c}{ Control soil (T2) } \\
\cline { 2 - 7 } & $\mathrm{C}_{\mathrm{bp}}$ & $\mathrm{C}_{\mathrm{AP}}$ & $\mathrm{RI}(\%)$ & $\mathrm{C}_{\mathrm{bp}}$ & $\mathrm{C}_{\mathrm{AP}}$ & $\mathrm{RI}(\%)$ \\
\hline $\mathbf{C u}$ & $55.68^{\mathrm{ab}}$ & $26.45^{\mathrm{b}}$ & $55.34^{\mathrm{a}}$ & $17.91^{\mathrm{c}}$ & $10.19^{\mathrm{cd}}$ & $43.11^{\mathrm{b}}$ \\
$\mathbf{Z n}$ & $76.22^{\mathrm{a}}$ & $48.06^{\mathrm{ab}}$ & $36.95^{\mathrm{b}}$ & $35.09^{\mathrm{b}}$ & $25.23^{\mathrm{c}}$ & $28.09^{\mathrm{bc}}$ \\
$\mathbf{P b}$ & $28.22^{\mathrm{bc}}$ & $19.58^{\mathrm{c}}$ & $30.61^{\mathrm{bc}}$ & $12.26^{\mathrm{cd}}$ & $9.61^{\mathrm{d}}$ & $21.56^{\mathrm{c}}$ \\
$\mathbf{N i}$ & $22.76^{\mathrm{c}}$ & $19.32^{\mathrm{c}}$ & $15.01^{\mathrm{c}}$ & $6.21^{\mathrm{d}}$ & $5.6^{\mathrm{d}}$ & $9.56^{\mathrm{d}}$ \\
$\mathbf{C d}$ & $3.11^{\mathrm{d}}$ & $1.49^{\mathrm{d}}$ & $5.22^{\mathrm{d}}$ & $1.01^{\mathrm{e}}$ & $0.97^{\mathrm{e}}$ & $3.15^{\mathrm{e}}$ \\
$\mathbf{C r}$ & $41.78^{\mathrm{b}}$ & $23.39^{\mathrm{bc}}$ & $45.01^{\mathrm{ab}}$ & $15.11^{\mathrm{cd}}$ & $9.64^{\mathrm{d}}$ & $36.22^{\mathrm{b}}$ \\
$\mathbf{A s}$ & $5.92^{\mathrm{d}}$ & $4.71^{\mathrm{d}}$ & $2.01^{\mathrm{d}}$ & $0.50^{\mathrm{e}}$ & $\mathrm{BDL}$ & - \\
\hline
\end{tabular}

$C_{b p}$ is concentration of heavy metal before planting, $C_{a p}$ concentration of heavy metal before planting and RI reduction index. Mean values with the different letter are significant different $(P<0.05)$ from each other at different concentration levels

Heavy metals accumulation in A. digitata seedlings: Assessing heavy metal uptake by plants from contaminated soils is very important for environmental studies because of the usage of the plants as biomonitors or hyper accumulators (Akintola and Bodede, 2019). Accumulation of heavy metals in $A$. digitata plants parts are shown in Table 4 while the rate at which they can transfer it to their parts (BCF) are presented in Table 5. The concentrations of heavy metals in seedling parts differ in response to the growing media. Higher concentrations of $\mathrm{Cu}$ (4.61 $30.11 \mathrm{mg} / \mathrm{kg}), \mathrm{Cr}(3.24-10.01 \mathrm{mg} / \mathrm{kg}), \mathrm{Zn}(5.88-$ $16.22), \mathrm{Pb}(1.41-4.84 \mathrm{mg} / \mathrm{kg})$ were recorded in the shoot than the root of the plants in the growing media while $\mathrm{Ni}(0.33-1.57 \mathrm{mg} / \mathrm{kg})$ and $\mathrm{Cd}(0.17-0.93$ $\mathrm{mg} / \mathrm{kg}$ ) were slightly higher in the root than the shoot. As was only found in the root $(0.14 \mathrm{mg} / \mathrm{kg})$ and shoot $(0.06 \mathrm{mg} / \mathrm{kg})$ of the seedlings grown in the sewage sludge.

Table 4. Heavy metal concentrations in plant parts

\begin{tabular}{lllll}
\hline $\begin{array}{l}\text { Heavy metals } \\
(\mathbf{m g} / \mathbf{k g})\end{array}$ & \multicolumn{2}{l}{ Sewage sludge (T1) } & \multicolumn{2}{c}{ Control soil (T2) } \\
\cline { 2 - 5 } & Root & Shoot & Root & Shoot \\
\hline $\mathbf{C u}$ & 16.01 & 30.11 & 3.08 & 4.61 \\
$\mathbf{Z n}$ & 9.83 & 16.22 & 4.25 & 5.88 \\
$\mathbf{P b}$ & 3.74 & 4.86 & 1.21 & 1.41 \\
$\mathbf{N i}$ & 1.57 & 1.56 & 0.33 & 0.27 \\
$\mathbf{C d}$ & 0.93 & 0.65 & 0.17 & 0.09 \\
$\mathbf{C r}$ & 6.65 & 10.01 & 2.23 & 3.24 \\
$\mathbf{A s}$ & 0.14 & 0.06 & - & - \\
\hline
\end{tabular}

Kabata-Pendias (2011) stated that $\mathrm{Cu}$ and $\mathrm{Zn}$ should not only be considered as soil contaminant but also as essential micronutrients for plant while Fernandes and Henriquues ( 1991) stated copper concentrations in non-hyperaccumulator plant shoots usually remain below $20 \mathrm{mg} / \mathrm{kg}$. However, in this study the copper concentration in the shoot of the plant grown in the sewage sludge is above $20 \mathrm{mg} / \mathrm{kg}$, thus A. digitata can be regarded as hyper accumulator of $\mathrm{Cu}$. Heavy metal uptake by plants from soil depends on the level of metal concentrations in the soil, time and other factors (Akintola and Bodede, 2019). Thus, low heavy metal uptake in the studied plant tissues (root and shoot) could be associated with low bio- availability of the metals in the growing media.

\begin{tabular}{lll}
\multicolumn{2}{l}{ Table 5. Values of Bioconcentration factors (BCF) } \\
\hline Heavy metal & Sewage sludge & Control soil \\
\hline $\mathbf{C u}$ & 1.88 & 1.50 \\
$\mathbf{Z n}$ & 1.65 & 1.38 \\
$\mathbf{P b}$ & 1.31 & 1.17 \\
$\mathbf{N i}$ & 0.99 & 0.81 \\
$\mathbf{C d}$ & 0.69 & 0.53 \\
$\mathbf{C r}$ & 1.51 & 1.45 \\
$\mathbf{A s}$ & 0.42 & - \\
\hline
\end{tabular}

The ability of plants to absorb heavy metals is expresses by the BCF. For most of the studied metals, the $\mathrm{BCF}$ was more than one and was generally higher for $\mathrm{Cr}, \mathrm{Zn}, \mathrm{Cu}$, and $\mathrm{Pb}$ (Table 6).

This agreed with the report of Kabata-Pendias and Pendias (2011), which stated that generally $\mathrm{Zn}, \mathrm{Cu}$, and $\mathrm{Pb}$ are more easily taken up by green plants. $\mathrm{BCF}$ values of As from plant grown in control soil were not determined because the concentrations in the seedlings parts were below detection limit. The $\mathrm{Ni}, \mathrm{Cd}$ and $\mathrm{As}$ of plants grown in the sewage sludge were lower than 1.

Conclusion: The significant reduction observed in concentrations of heavy metals in soils before and after planting indicated their enrichment in the plant tissues. Bioconcentration factors indicated that the plants can be used as bioaccumulator plant. This study has shown the efficacy and ability of Adansonia digitata to accumulate and distribute heavy metals in its tissue parts. Thus Adansonia digitata seedlings can be used to clean or rehabilitate soils that are contaminated with the studied heavy metals. 


\section{REFERENCES}

Akintola, OO (2019). Heavy Metal Uptake and Growth Response of Jatropha curcas Linnaeus Seedlings in Spent Oil Contaminated Soil. Inter. J. Appl. Res. Technol., 8(2): $106-114$

Akintola, OO; Bodede, IA (2019). Distribution and Accumulation of Heavy Metals in Red Cedar (Cedrela odorata) Wood Seedling Grown in Dumpsite Soil. J. Appl. Sci. Environ. Manage. 23 (4): 811-817.

Amos-Tautua, BMW; Onigbinde, AO; Ere, D (2014). Assessment of some heavy metals and physiochemical properties in surface soils of municipal open waste dumpsite in Yenagoa, Nigeria. Afr. J. Environ. Sci. Technol., 8 (1):4147

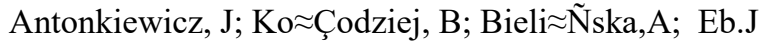
(2016). The use of reed canary grass and giant miscanthus in the phytoremediation of municipal sewage sludge. Environ. Sci. Pollute. 23: 95059517

Carbonell, G; Pro, J; Gomez, N; Babin, MM; Fernandez, C; Alonso, E; et al. (2009).Sewage sludge applied to agricultural soil: ecotoxicological effects on representative soil organisms. Ecotox. Environ. Saf. 72:1309-1319.

Chu, S; Wu, D; Liang, LL; Zhong, F; Hu, Y; Hu, X. et al. (2017). Municipal sewage sludge compost promotes Mangifera persiciforma tree growth with no risk of heavy metal contamination of soil. Sci. Rep. 7:134-142.

Cocarta, DM; Subtirelu, VR; Badea, A (2017). Effect of sewage sludge application on wheat crop productivity and heavy metal accumulation in soil and wheat grain. Environ. Eng. Manage. J. 16, 1093-1100.

DPR (Department of petroleum resources) (2002). Environmental guidelines and standards for the petroleum industry in Nigeria (revised ed.). Nigeria: Ministry of Petroleum and Natural Resources, Department of Petroleum Resources.

Eid, EM; Alrumman, SA; El-Bebany, AF; Hesham, AEL; Taher, MA; Fawy, KF (2017). The effects of different sewage sludge amendment rates on the heavy metal bioaccumulation, growth and biomass of cucumbers (Cucumis sativus L.). Environ.Sci. Pollut. 24:16371-16382.
Fernandes, JC; Henriques, FS (1991). Biochemical, physiological, and structural effects of excess copper in plants. Bot. Rev. 57:246-273.

Fijalkowski, K; Rorat, A; Grobelak, A; Kacprzak, MJ (2017). The presence of contaminations in sewage sludge - the current situation. J. Environ. Manage. 203:1126-1136.

Grobelak, A; Placek, A; Grosser, A; Singh, BR; Alms, ÖR; Napora, A; et al. (2017). Effects of single sewage sludge application on soil phytoremediation. J. Clean. Prod. 155:189-197.

Guidi Nissim, W; Labrecque, M (2016). Planting microcuttings: an innovative method for establishing a willow vegetation cover. Ecol. Eng. 91, 472-476

Guidi Nissim, W; Palm, E; Mancuso, S; Azzarello, E (2018). Trace element phytoextraction from contaminated soil: a case study under Mediterranean climate. Environ. Sci. Pollut. 25:9114-9131

Ideriah, TJK; Harry, FO; Stanley, HO; Igbara, JK (2010). Heavy metal contamination of soils and vegetation around solid waste dumps in Port Harcourt, Nigeria. J. Appl. Sci. Environ. Manage. 14 (1):101-109

Kabata-Pendias, A (2011). Trace Elements in Soils and Plants. CRC Press, Boca Raton.

Kacprzak, M; Neczaj, E; Fijałkowski, K; Grobelak, A; Grosser, A; Worwag, M; Rorat, A; Brattebo, H; Almas, A; Singh, BR; (2017). Sewage sludge disposal strategies for sustainable development. Environ. Res. 156:39-46.

Kelessidis, A; Stasinakis, AS (2012). Comparative study of the methods used for treatment and final disposal of sewage sludge in European countries. Waste Manag. 32:1186-1195.

Leila, S; Mhamed, M; Hermann, H; Mykola, K; Oliver, W; Christin, M (2017). Fertilization value of municipal sewage sludge for Eucalyptus camaldulensis plants. Biotechnol. Rep. 13:8-12

Liphadzi, MS; Kirkham, MB (2006). Heavy metal displacement in chelate-treated soil with sludge during phytoremediation. J. Plant Nutr. Soil Sci. $169,737-744$. 
Marcel, VDP (2006). Soil and water contamination from molecular to catchment scale. London: Lewis Publishers.

Mininni, G; Di Bartolo Zuccarello, R; Lotito, V; Spinosa, L; Di Pinto, A.C (1997). A design model of sewage sludge incineration plants with energy recovery. Water Sci. Technol. 36, 211-218.

Obute, CC; Ndukwu, BC; Eze, E (2010). Changes in species diversity and physic-chemical properties of plants in abandoned dumpsites in parts of Port Harcourt, Nigeria. Scientia Africana. 9(1): 181193

Roades, JD (1996). Salinity: electrical conductivity and total dissolved solids. In: Sparks, D.L. (Ed.), Methods of Soil Analysis, Part 3, Chemical Methods. SSSA Book Series n.5.

Sreelal G; Jayanthi, R 92017). Review on phytoremediation technology for removal of soil contaminant Indian. J. Sci. Res. 14(1):127-130

Suchkova, N; Alifragkis, D; Ganoulis, J; Darakas, E; Sawidis, T; Stolberg, F (2015).Reclamation with phytoremediation of area affected by sewage sludge at the Thessaloniki wastewater treatment plant in Sindos (Greece). Toxicol. Environ. Chem.97:03-115

Suchkova, N; Tsiripidis, I; Alifragkis, D; Ganoulis, J; Darakas, E; Sawidis, T (2014). Assessment of phytoremediation potential of native plants during the reclamation of an area affected by sewage sludge. Ecol. Eng. 69, 160-169.

Wołejko, E; Łozowicka, B; Kaczynski, P; Konecki, GM (2017). The influence of chemical protection on the content of heavy metals in wheat (Triticum aestivum L.) growing on the soil enriched with granular sludge. Environ. Monit. Assess. 189 (8):424-431

Wyrwicka, A; Urbaniak, M (2018). The biochemical response of willow plants (Salix viminalis L.) to the use of sewage sludge from various sizes of wastewater treatment plant. Sci. Total Environ. 615: 882-894

Zhang, H; Zhang, S; Xu, X; Li, T; Gong, G; Jia, Y; Li, Y; Deng, L (2010). Tolerance and accumulation characteristics of cadmium in Amaranthus hybridus L. J. Haz. Mater. 180: 303-308. 